\title{
Deforestation and Social Resilience: A Case Study of Gunung Mas District-Central Kalimantan
}

\author{
Herman Hidayat ${ }^{1}$, Ernawati Sinaga ${ }^{2}$ \\ ${ }^{1}$ Graduate School of Social and Political Science, Universitas Nasional, Jakarta, Indonesia \\ ${ }^{2}$ Graduate School of Biology, Universitas Nasional, Jakarta, Indonesia
}

Email address:

hermanhidayat246@gmail.com (H. Hidayat),ersinaga2003@yahoo.com.sg (E. Sinaga)

\section{To cite this article:}

Herman Hidayat, Ernawati Sinaga. Deforestation and Social Resilience: A Case Study of Gunung Mas District-Central Kalimantan. Earth Sciences. Vol. 10, No. 1, 2021, pp. 17-26. doi: 10.11648/j.earth.20211001.13

Received: January 27, 2021; Accepted: February 14, 2021; Published: March 3, 2021

\begin{abstract}
A Current condition the trend of deforestation was decreasing in Indonesia. According to Minister of Environment and Forestry statement (January 29, 2018) the rationale was happened due to that the government released policy for keeping moratorium of estate oil palm concession permission, to implement law enforcement for illegal logging actors, to launch forest restoration program and conservation in protected forest and peat swamp land, and to invite participation of local people for social forestry (Perhutanan Sosial). There is close relation that deforestation issues affect on ecological damage and social resilience and eventually affect on poverty among local community who live in and around forest and people as well. As an illustration ecological damage for instance forest fire, flood, drought, soil erosion, extinction of biodiversity and so forth due to deforestation impact. On the other hand, deforestation eventually affect on social resilience and poverty was indicated more ten percent that marginalized society (they categorized poor) below average national income, no access to land utilization and lower education still high. As registered by National Bureau Statistic (BPS) in 2018 reached 9,82 percent and 10,12 percent in 2017 (total 23,8 million) from 268 million people. From this point of view, the paper focuses on discussion three level analysis to reply deforestation that eventually affect on social resilience. Firstly, is to examine government policy toward private sectors on moratorium of oil palm estate plantation and land conflict. Secondly is shifting cultivator changed into mining activities to respond forest degradation. Thirdly is to invite participation of local people and to carry out social forestry (Perhutanan Sosial) program which aims to promote their income and social welfare and to maintain the sustainability of forest ecosystem.
\end{abstract}

Keywords: Government, Private Sector, Local People, Mining Activities, Social Forestry, Law Enforcement

\section{Introduction}

Deforestation and changes in forest ecology have occurred in various regions in Indonesia. Meanwhile, forest management that does not involve local communities has an impact on the extreme 'inequality' of income between migrants who work for private companies in the forestry sector. This condition occurred under the policies of the Soeharto Regime (New Order), which issued a policy of granting forest management rights (HPH) concessions in the late 1960s and 1980s and industrial plantation forests (HTI) in the late $1980 \mathrm{~s}$ for private companies to supply raw materials for the forestry industry (sawmill, plywood, and pulp and paper) $[1,2]$. Government policies that position the forestry sector 'to earn foreign and domestic foreign exchange' for capital for development and economic growth have a wide impact on ecological damage and inequality of economic income between capital owners, government bureaucrats, and local communities. The implication of granting concession permits (HPH and HTI) which takes sides with the private sector and ignores the cooperative sector and local communities, there is a 'marginalization' of economic income, economic and social resilience that is vulnerable and falls to the stage of impoverishment for people living around forests and in Forest. On the other hand, the ecological impact is also large, there is 'ecological damage', including deforestation, forest fires, air and environmental pollution, floods, soil erosion, illegal logging, and so on.

In Indonesia, due to deforestation, the area of our tropical 
forest cover in the 1980 s to 2000 s experienced a reduction of almost 40 million $\mathrm{Ha}$ of the forest area and left around 120 million hectares which previously registered 162 million $\mathrm{Ha}$ in 1950s [3]. This is related to changes in forest cover that affect the sources of income for the people living around the forest and in the forest. Therefore, changes in forest ecology have a positive correlation with the 'social resilience' of the people living around the forest. Because the potential of forest resources can be enjoyed by communities living around forests and villages, not only have direct economic value, but also in indirect economic form [4], including the management of 'environmental services'.

\section{Methodology}

This paper examines the concept of 'social resilience' to see changes in forest ecology associated with people's lives. Social resilience referred to in this study refers to the thought Webersik [5] which says that 'social resilience is used to describe how a community can adapt to or adapt to external pressures received or to an environment that is changing'. Meanwhile, the opinion of Berkes et al.,[6] defines 'social resilience as an important element of how a community deals with environmental changes. Social resilience is not something static, but it is dynamic and can even be raised according to circumstances. In the context of implementing two mutually supporting concepts of social resilience from Berkes and Webersik, the author examines changes in forest ecology and deforestation that occur in Gunung Mas district (Figure 1) in the findings of a 2015 field research and carried out several interview with informant and participatory observation on three levels of discussion analysis, including 1) how local communities respond to ecological changes on expansion of private companies in the expansion of oil palm plantations, mining activities, forest concessions (HPH) and industrial plantations (HTI); 2) some of the community shifted their livelihoods from hunting animals, looking for wood and non-timber in the forest or from rice cultivation to gold mining, because they saw that the work was more profitable; and 3) the community is invited by government policy to participate in the 'social forestry' (Perhutanan Sosial) program for economic, social empowerment and maintaining the forest ecosystem so that it remains sustainable.

\section{Results and Discussion}

\subsection{Private Company and Land Conflict}

The role of government is very significant. The government represents by Ministry of Agriculture and Ministry of Forestry give concession permission to private companies to carry out on oil palm estate plantation, logging forest concession (Hak Pengusahaan Hutan/HPH) and industrial timber plantation (Hutan Tanaman Industri/HTI). The Development of oil palm plantation is very rapid due to it became 'lucrative business' among other estate plantations in Indonesia. Indonesia government received foreign exchange earning about US\$ 5 billion and absorbed job creation' reached 2.5 million for local people in 2000s. As of early 2011. Palm oil plantations covered 7.8 million ha in Indonesia and rapidly develop to became 10.8 million ha in 2015 and eventually reached 16.3 million ha in 2019 [7], previously, between 2006 and 2010, palm oil cultivation covered only 5.9 million ha [8]. In 2010, these plantations produced 22 million tons of crude palm oil (CPO), by the end of 2011, CPO production had increased to 23.6 million tons [9] and rapidly increased to became 47.1 million tons of CPO in 2019. Of this quantity, 15.5 million tons of CPO were allocated for export. Investors received IDR 122.7 trillion in foreign exchange earnings, and the government received just IDR 14 trillion in CPO taxes [10]. But, the income of foreign exchange earnings reached US\$ 20 billion in 2019 and US\$ 21 billion by 2020 [7]. Most plantations and CPO production sites were located in Sumatra and Kalimantan, and the rest in Papua.

The expansion of oil palm plantations in Kalimantan, especially Central Kalimantan occurred in the 2000s. It was registered 574,000 for plantation oil palm in Central Kalimantan in 2019 [7]. The expansion of oil palm plantations totaling hundreds of thousands of hectares was carried out by 114 units of private companies in 2015-2019. The presence of oil palm plantations obtained permits for business use (HGU) in the Land Use Allocation (APL) and production forests for conversion (HPK) covering 371,000 hectares in Gunung Mas District-Central Kalimantan (Table 1). The implication of granting HGU concession permits has resulted in social and ecological conflicts with local communities. There have been 127 recorded land conflicts in private plantation areas with local communities in Central Kalimantan.

Table 1. Width and Function of Forest Area in Gunung Mas District 2014.

\begin{tabular}{lll}
\hline Forest Function & Width area (Ha) & Percentage (\%) \\
\hline Protection Forest & $59,136,64$ & 5,47 \\
Production Forest & $374,968,50$ & 34,71 \\
Limited Production Forest & $275,738,36$ & 25,52 \\
Production Forest for Conversion & $178,077,49$ & 16,48 \\
Land use Allocation (APL) & $192,479,01$ & 17,82 \\
Total & $1,080,400,00$ & 100,00 \\
\hline
\end{tabular}

Source: Based on Ministry of Environment and Forestry Decision Number 529/Menhut II-2012. 


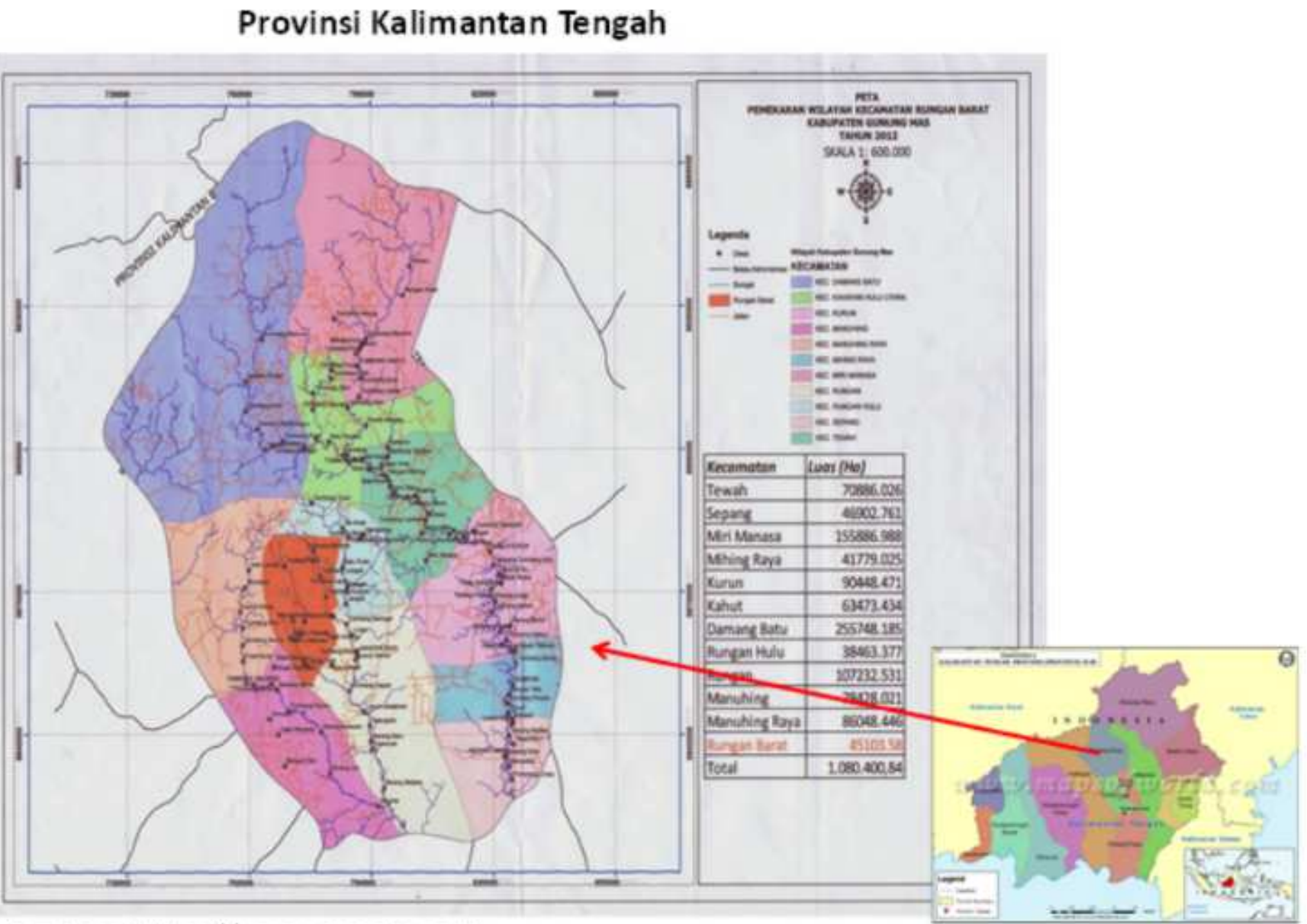

Sumber: https://www.google.co.id

Source: https:www.google.co.id

Figure 1. Map of Gunung Mas district, Central Kalimantan.

The Ministry of Forestry has issued production forest for conversion areas for Land Use Allocation (APL) for several companies such as Gumas Alam Subur, Kurun Sumber Rezeki, Citra Agro Abadi, South Barito and Mitra Jaya Cemerlang. However, problems arose on the ground, resulting in potential land conflicts. Among the problems that arise are those without an environmental permit (Amdal), plantation business permits (IUP), opening forest areas outside concession boundaries, and companies operating in peat swamp areas that are more than 3 meters deep (prone to forest fires). Besides, the Ministry of Forestry also allocated 649,706 hectares of production forest for business permits for utilization of timber forest products (IUPHHK) and industrial plantations (IUPHTI) from 1999-2013 to 11 companies $^{1}$. In addition to giving to 11 companies that hold IUPHHK, there are also production forest areas in Gunung Mas Regency that are lent to gold and coal companies. This means that mining activities participate in 'controlling' the forest area in the

1 Among 11 companies of IUPHHK were operated in Gunung Mas district for instance Sikatan Wana Raya, Hasil Kalimantan Jaya, Hutan Domas Raya, Bumimas Permata Abadi, East Point Indonesia, Taiyoung Engreen (Hutan Tanaman Industri/Industrial Timber Plantation), Carus Indonesia, Rinanda Inti Lestari, Dwima Jaya Utama, Fitamaya Asmafara and Puspa Warna Camerlang (Forestry Agency Office in Gunung Mas District, 2015). district. In 2015, there were about 6 companies carrying out mining activities in forest areas that were still in the exploitation stage in the production forest area of $171,360 \mathrm{Ha}$ which was loaned by the Ministry of Forestry. On the other hand, the 6 companies, if they cannot manage forest areas and destroy the forestry ecosystem, their operating permits can be revoked.

This land and ecological conflict arises, according to the perception of the local community, that private companies are taking community land areas and violating land boundaries with customary forests; does not apply environmental and sustainable planting; the practice of burning land which results in forest fires and the appearance of smoke that disturbs the health of residents; application of pesticides to ward off pests, so that the pesticide liquid during the rainy season enters the Kahayan River which causes water pollution. As a result of water pollution, during the dry season, many river biotas such as fish and shellfish and water become died and polluted when consumed by local people. This critical condition eventually affect on deforestation and economic marginalization due to customary forest rights eventually affect on degradation and income from forest products was decreasing (Interview with $\mathrm{Z}$ on May 10,2015). Among the private oil palm companies 
that have been operating include Kahayan Agro Plantation (KAP), Flora Nusa Perdana, Nusantara Sawit Persada, and Prasetya Mitra Muda.

As an illustration of the land conflict between private company Kahayan Agro Plantation (KAP) and local Dayak communities that occurred on July 14, 2015. The local community reported and was facilitated by two nongovernmental organizations (NGOs), namely the Independent Forestry Monitoring Network (JPIK) and Telapak. This land conflict report has been reported to the Regional Police (Polda) of Central Kalimantan. News of this conflict indicates that the KAP company has seized the 'rubber' plantation area of the Dayak community in Tumbang Marikori village, Damang Satu subdistrict. In the deliberation between the two parties, the company finally agreed to replace the amount of money as land 'compensation' fees that had been used by the company.

Another case also occurred in land conflicts regarding land 'grabbing' and 'burning' of land by companies and local Dayak communities in Mantuhe Village, Manuhing Raya Subdistrict regarding the installation of Hinting Pali. Hinting is installed by installing a portal by the local community. The aim is for the company to pay attention to the demands of the local community to compromise 'pay' for the demands of the indigenous people. ${ }^{2}$ As a result of this hinting installation, the mobility of transportation and company employees is disrupted to operate the company's activities. The hinting conflict solution was facilitated by the adat head, either mantir (village customary head) and Damang (district-level customary head) to compromise between the company and the local community. It was agreed that to reopen the hinting on May 25, 2013, a customary fine was imposed for the payment of IDR 200 million and the manager of the company Ibrahim Lisaholit and the court convicted the company manager. Meanwhile, a representative from the Central Kalimantan Parliament (Dewan Perwakilan Rakyat Daerah/DPRD) recommended that the company's license be revoked because it was proven that it had burned land to plant oil palm trees, but the DPRD member rejected the demands of the DPRD members in court (interview with Y, May 11, 2015).

Observing the discussion above regarding production forest areas used for oil palm plantation activities, management of IUPHHK and HTI as well as gold and coal mining by private companies has implications for the process of changing 'forest cover' and 'forest degradation'. The changing condition of the forest area has disturbed the access

2 The installation of 'hinting pali' is an implementation of the Dayak tribal tradition of judging that the behavior of private entrepreneurs has violated customary law, due to land grabbing factors, destroying ancestral burial sites and locations that are considered sacred to the Dayak indigenous people, and so on. The solution is to open a portal that uses the 'hinting pali' symbol, if the company pays a 'customary fine' agreed by both parties and facilitated by Mantir (head of Dayak custom at the village level) and Damang (head of Dayak customs at the district level) and government officials (Tripida: Head of sub-district, village head, sectoral police station / Polsek and sub-district military office (Koramil) (Interview on May 12, 2015 with Mantir (in Kuala Kurun sub district, Gunung Mas district). of the people who live around the forest or customary communities who have customary forests and sometimes the existence of the forest is threatened. This condition has an impact on the 'social resilience' of forest communities to be disturbed, because they have a large dependence on forest resources.

\subsection{From Shifting Cultivation to Mining Cultivator: Respond to Forest Degradation}

The agricultural system of the Dayak people in Gunung Mas Regency is shifting cultivation (rotating fields) as local wisdom and concern for nature. The practice of shifting cultivation is a production system in which the protection of land, water, forest and animals around it is considered. In other words, the practice of shifting cultivation is to protect the existence of natural resources in order to meet the needs of children and grandchildren for natural resources in the future [11]. Therefore, the exploration carried out did not exceed the carrying capacity of natural resources. As a result, the Dayak community in managing natural resources as an implementation of their local wisdom has been practiced in a sustainable manner. There are two types of plants used in shifting cultivation, they are rice cultivation, rubber and rattan trees. Each head of the Dayak community has 2-4 ha of land for rubber and rattan. However, due to environmental degradation and forest ecosystems, due to large plantation practices such as oil palm, industrial plantations (HTI), logging forest concessions (HPH) and mining activities, they no longer get natural resources that can support their basic needs. As a result, the practice of shifting cultivation cannot be maintained forever, because the forest area they manage is getting smaller, there are land conflicts with private companies, the government is taking forest areas for conservation forest areas and making dams (water dams) for irrigation water resources for community agriculture and also an increase in the number of Dayak people in an area, so that the land for farming is narrower [4]. It is obvious fact of the many external factors that have implications for the narrowing of the Dayak people's land above, it is the result of the conversion of forest functions to plantation areas for dozens of oil palm plantations and forestry industries such as logging forest concessions (HPH) and industrial tree plantations (HTI) and mining. As a result, it is impossible to clear new forest lands to be allocated as new cultivation areas. On the other hand, the repeated use of fields has an impact on soil fertility, so that the yield of soil productivity decreases. As a result, the fields they manage are not sufficient to meet their food needs for their families for one year.

In addition to the decreasing results of shifting cultivation, the results are coupled with the decreasing price of rubber and rattan, adding to the difficulty of people's income. As an illustration, in 2013, the commodity price of rubber only reached Rp. 600,000 / per quintal. Even though the price of rubber once exceeded the price of Rp. 1,000,000 / quintal 2000-2006. In September 2014, the price of rubber in Central Kalimantan, especially in Gunung Mas and Tabalong 
Districts as rubber-producing centers, was only Rp. 9,00015,000 / per kg. According to Centre of Statistic Agency (BPS) data for September 2015, the export value of rubber in the January-August 2015 period reached US\$ 4.08 billion or decreased by $18.53 \%$ from the same period last year (2014) of US\$ 5 billion. Meanwhile, if viewed from the volume of exports, in the January-August 2015 period rubber shipments reached 2.22 million tons or decreased $0.42 \%$ in the same period last year (2014) which reached 2.23 million tons. From January to August 2015, the price of rubber fell by $13.41 \%$ compared to that in July at US \$ $164 /$ metric ton. According to the Association of Indonesian Rubber Companies (Gapkindo), it was reported that the low price of rubber was unable to raise the rate of global and domestic demand for this commodity. As a result, according to Gapkindo, until the end of September 2015, the international market had not shown the 'courage' to buy rubber commodities aggressively. Therefore, due to low rubber prices, farmers are not enthusiastic about taking care of rubber plantations and sadly their young people no longer see agriculture as a future life.

Besides that, the price of other commodities such as rattan also experienced a decline in price, the price of raw rattan reaching Rp. 1,200-Rp. 1,500 kg. This price is down from 2 years ago (2010) which reached Rp. 2,000/kg. Meanwhile, for polished or semi-finished rattan, the price reaches $\mathrm{Rp}$. $20,000 / \mathrm{kg}$ or down from the price of the previous 2 years (2010) of Rp. 25,000 / kg. Rational reasons, the price of rattan tends to decreased due to the 'moratorium' on rattan exports. On the other hand, the cause of the depressed price of rattan is the 'decrease' of uptake from the rattan and furniture industry in Java as the industrial center, including Cirebon, Surabaya and Bekasi for domestic and international markets.

The shift from the livelihood practices of the agricultural sector, especially rice cultivation, rubber and rattan farming, and seeking non-timber forest products to becoming traditional gold miners is very unfortunate. Because in fact, Gunung Mas Regency is a rubber producer for the entire province of Central Kalimantan. Its rubber production reaches 5,000 tons per month, so that the impact of reducing rubber production from local revenue (PAD) for Gunung Mas Regency will be replaced by other districts. In the course of time, 2001 became the starting point for the people of Gunung Mas to mine gold using machines. If the time to pan for gold must be done in river channels, then gold mining with new machines or this new technology [12] can be done on dry land (land) and beach of river as well. There are two types of mining with this new system, namely the lanting system and the broomstick system. The lanting method is the extraction or suction of gold sand from the ground using a straw machine. The labor required is around 2 to three people. Meanwhile, the mining method using broom cutting is that the stripping of the top layer of soil must be removed first. After the handling is complete, the material is sucked in by a machine. The labor required with the broom cutting system is around 6-7 people.
Below is described, a traditional gold miner who practices operations on the river bank named Aris Tanto who is 31 years old. Tanto has worked for 10 years, since 2005 (Interview with X, May 8, 2015). Tanto works as an operator of the Kato brand of sand suction machine made in China. Usually Tanto is assisted by two of his assistants. Machine owners, usually investors, are native Dayaks and immigrants, they buy a Kato machine for Rp. 25-30 million in the city of Palangka Raya. The system of division of labor is "half and half" divided after the operational cost is taken, the remainder is divided in half between the machine owner and the field worker (50:50). The results of gold mining, if it is good, the results can get more than 100 grams ( 1 ounce) in mid-2013. The price of gold in grams at Palangka Raya stores is around Rp. 400,000-435,000. However, the yield of gold mining is uncertain, sometimes receiving only 10-15 grams per day. According to Tanto, from the income earned from panning for gold, half of his income is saved in the bank to prepare for the education of his children and the availability of medical costs, because miners are very susceptible to lung disease, malaria and itchy skin usually exposed to mercury fumes. There are several technical obstacles in the gold mining operation. First, the regional Industry Office does not provide technical training guidance in productive and efficient gold mining operations. Second, the Cooperative Office, does not provide access to financial 'credit' or credit for strengthening operational capital Third, the Health Office does not provide protection and health education to gold miners operating along rivers and on land to prevent lung disease, malaria and itchy skin due to exposed to mercury contamination.

In the development of gold mining in 2006, the number of community gold mines in Gunung Mas Regency was recorded at 3,630 miners with 726 vacuum machines [13]. This figure means that the people who depend on this smallscale gold mining are very large. This condition means that there are indications that the results of traditional mining activities are profitable. However, the government considers the people's mining activities to be illegal, because it damages the environment and pollutes river water, resulting in water pollution in the Kahayan River. The economic, social and environmental impacts of community mining activities on the riverbanks and on land for local communities have already been felt the damage in 2015 and the years to come. Actually, regional regulations related to gold mining already exist. This regional regulation invites community miners to legalize their mining activities by arranging 'permits' for mining activities, so that they are easily controlled by government officials. However, local gold miners do not pay attention to regional regulations, because the area that has been granted a permit is recorded at only 10 hectares, whereas the potential for gold in that area (10 hectares) does not necessarily produce results. In other words, for the people's perception of miners, it is useless for traditional miners to take care of a permit with a number of fees and administration, if the gold yield on the land is not available. Therefore, the level of speculation when working 
on a plot of land to be used as a mining site is so high.

As a result, gold mining has become the people's choice in Gunung Mas Regency, for the reason that the gold potential in the region is large. In addition, the selling price of gold is high. As an illustration in 2015 , the gold price at the mining level reached Rp. 420,000 / gram. Selling gold mined is relatively easy. And the stable and rising price of gold is one of the global commodities. As a result, the price of gold follows international prices. With the potential for gold that spreads in almost all districts, causing the need for labor for this people's gold mining activities is high. Therefore, mining for gold is compared to working in the agricultural sector (farming for rice cultivation) which requires a long production and harvesting process of around 4-5 months to get results, some people in Gunung Mas prefer to work in traditional and modern gold mining in private companies. Local wisdom for shifting cultivation has begun to be disturbed by the attitude of life of "hedonism" (loving the acquisition of property), so that people like businesses that can generate immediate money. On the other hand, rubber plantations that have long been struggling for the livelihoods of their owners have begun to be abandoned and shifted. The reasons they put forward are because the price of rubber in the past 10 years (2005-2015) has decreased, so that the results of rubber gardening are not profitable and rubber plants are no longer being taken care of by the owners.

The results of gold mining in the Gunung Mas community have seen results in increasing income and welfare. This can be seen from the increase in house repairs from wood to concrete construction materials and also ownership of motorized vehicles, including motorbikes and some who own cars. Thus, the source of the economy and community income has shifted from agriculture to mining which is facing the challenges in improving economic income, but the opposite also brings in ecological damage for instance water and river pollution that affect to economic, social and ecological of local communities at large.

\subsection{To Invite Local People on Social Forestry}

During the last decades of the 2010s, Indonesia's forestry community saw growing resistance to state-centered forest management systems. The opinion that states is the only development actor and resource guardian that is legitimately considered to be the root cause of the forestry problem today includes deforestation, forest fires, social conflicts related to forest land, especially outside Java [14]. Besides, the rational reason is related to "poverty" condition. Village communities living around the forest are in 'poverty' to be able to participate in managing forest resources, so that they are economically and socially empowered and earn income. According to the Central Statistics Agency (Badan Pusat Statistik/BPS) in 2014, the number of poor people in Indonesia reached 11.25 percent or 28.28 million people and on average they live around forests and in forests [15]. As a result, as a response to the collapsed centralization system, many people including NGO officials proposed alternatives to community-based forest management or what is known as 'social forestry' (Perhutanan Sosial). This alternative is usually considered more likely to deal with the complexities of social, economic and ecological problems outside Java and also to deal with the sharing of economic benefits from forests which have been considered unfair. In fact, nongovernmental organizations (NGOs), academia, international agencies (WWF, Lestari USAID, Telapak, International Conservation, World Resources Institute, and so on), and other environmental activists have long tried to influence policy changes from centralization, support for corporations towards community-based forest management. Thus, the policy changes at the end of 2010, particularly the Jokowi and Jusuf Kala administrations (2014-2019), which issued a "social forestry" policy in April, 2016.

The understanding of social forestry is a sustainable forest management system implemented in a state forest area or customary / customary forest which is carried out by the local community to improve community welfare, environmental balance, and socio-cultural dynamics. The government spent 12.7 million $\mathrm{Ha}$ for 'social forestry' through 5 schemes, including: 1) village forest (HD); 2) customary forest (HA); 3) community forest (HKM); 4) community plantation forest (HTR); and 5) forestry partnerships (KK). In the realization of social forestry in November 2018, it has released 2.13 million $\mathrm{Ha}$ or $16.8 \%$ of the total target of 12.7 million Ha. Social forestry is given access to forest management for 35 years by the government to local communities and farmers. Access to management gets economic incentives in the form of credit for capital assistance, market access and assistance from the government and non-governmental organizations (NGOs). It can be extended again, after there is an 'evaluation' from the Directorate General of Social Affairs.

According to the former Coordinating Minister for Economy, Finance and Industry (EKUIN) Darwin Nasution, 'social forestry' is designed and aims to provide communities with access rights to manage forest areas as part of the 'National Agrarian Reform' policy. The aim is to accelerate economic equality, especially in relation to the availability of land for small community groups. This program is related to one of the "important instruments for increasing economic income and farmer welfare, reducing unemployment and reducing poverty levels", said Darmin. ${ }^{3}$ With regard to the implementation of provincial 'customary forests' in Central Kalimantan, what was said by Iber Djamal (77 years), a Dayak Ngaju figure from Pilang Village, Pulang Pisau Regency, that the designation of customary forests' is 'a thirst in the midst of dryness of justice for indigenous peoples.' Threats and violence are faced by indigenous peoples so that they are closer to their ancestors and become more attached to culture'[16]. As a result, the struggle of Iber and his friends and facilitated by Yuliana Nona, a manager of NGOs USAID Lestari, obtained 102 hectares of 'Barasak Island' customary forest with this protected refuge to become the

3 Puput Andi Sukarno, "Program Perhutanan Sosial Mencapai 2,13 Juta Ha," dalam Warta Financial, 11 November 2018. Diakses di Google, 12 November 2018 . 
only customary forest in Central Kalimantan through the 'social forestry' scheme.

According to the Head of Social Forestry Division of the Central Kalimantan Provincial Forestry Service, Ihtisan said that so far, his party 'trying to encourage district / city governments to work harder and seriously work on social forestry, including customary forests.' However, the majority of them do not understand the rules and regulations [19]. In the case of customary forests in Central Kalimantan through the 'social forestry' scheme. To date, in the social forestry scheme, data from the Forestry Service of Central Kalimantan Province, there are 151 permits with a total area of 205,381 ha. As an illustration nationally, according to data from the Ministry of Environment and Forestry (KLHK), 75 customary forests have been stipulated by Decree (SK) for 75 customary forest communities (MHA) with 39,371 ha of families in an area of 56,903 ha in 15 provinces. In addition, 1.1 million ha of area in 19 provinces have been delineated as customary forest. According to the management of the Customary Territory Registration Agency (BRWA), since (2016) they have mapped their customary forest areas that have been guarded for generations. Of the 16,000-ha mapped, now nearly 3,000 ha have been replaced by oil palm plantations. This fact is still denied by the local government, that there is no customary forest in Lamandau. In fact, the National Indigenous Peoples Alliance (AMAN) Central Kalimantan and $B R W A$ have over the years mapped at least 12 'participatory' maps in Central Kalimantan, including in Lamandau, covering an area of 119,777 ha [19]. According to Ferdi Kurnianto, Acting Head of the Central Kalimantan AMAN Regional Daily Executive Agency, said that it is difficult for their institutions to help the community to get government recognition. Even for regional mapping operational techniques, they have to 'share' money and logistics with the community.

\subsection{The Practice of Customary Forest Rights}

According to the staff of the Gunung Mas District Forestry Service, in the next five years (2014-2018) the vision of the forestry sector is 'to realize productive and sustainable forest sector development'. So by considering the potential, conditions, problems, challenges, opportunities and strategic issues, the vision of the Regency is "Mount Mas Shining, Competitive, Self-reliant, Prosperous and Dignified" (Interview X, 17 May 2015). So, to realize this vision, The Forest Service Office collaborates with other agencies to determine the following missions, namely:

1) Improving forest management on a sustainable basis; 2) increasing the capacity of human resources (HR) in the forestry sector; 3) develop local community participation in social forestry management.

As we know, the forest potential in Gunung Mas Regency is very large. More than 65 percent of the 1,080,400-ha forest area allocated for production forest managed by the private sector for forestry concession permits including IUPHPH and IUPHTI, and 25 percent for oil palm plantation) and mining, and 5-7 percent for 'social forestry' allocation. As an illustration, the designation of customary forest covering an area of 5,010.96 hectares is designated as 'protected forest' to be created 'People Forest Park' (Taman Hutan Rakyat/TAHURA) based on an environmental impact analysis study (Amdal) (Figure 2). The idea for the formation of Tahura was invited Pro and contra. Among the party of pro was initiated by Hambit Binti, former Regent of Gunung Mas (2001-2014), province, central government and NGOs engaged in conservation (WWF, USAID-Lestari, Walhi, Telapak, etc.) for water catchment, conservation of flora and fauna biodiversity (Figure 3). This is related, because the location of Lapak Jaru is very strategic in the upstream river sources, including the Kurun, Sepan, Dajung, Panakon, Bahandang and Bahenas rivers.

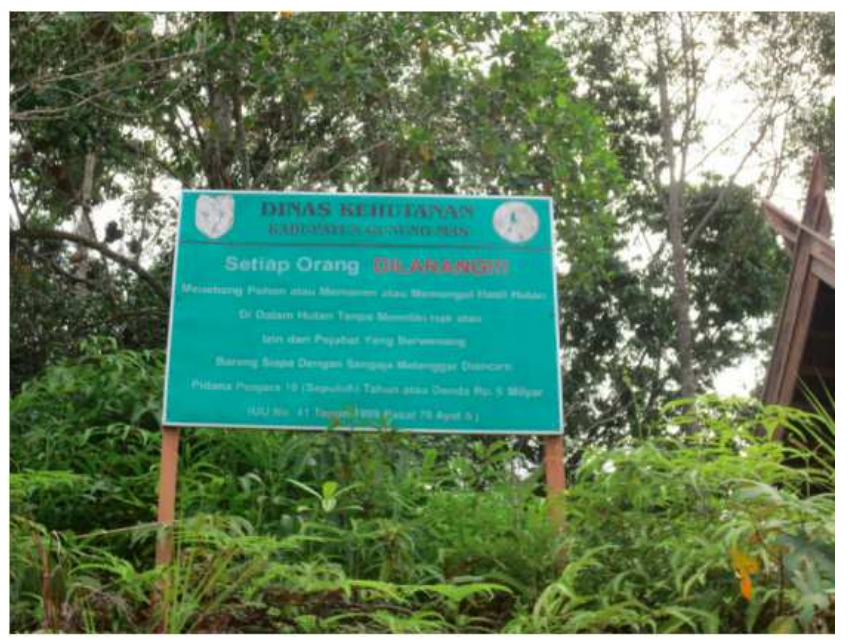

Figure 2. Lapak Jaru cite appointed as Tahura area in Gunung Mas District. Source: (individual photo), May, 2015.

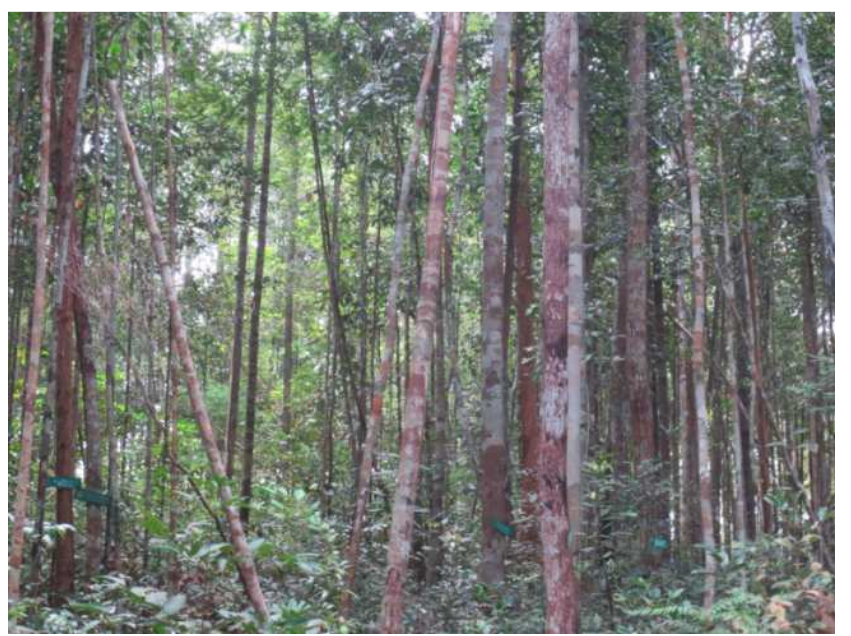

Figure 3. Protected forest in Lapak Jaru area for biodiversiy conservation (flora and fauna). Source: Individual Conservation May, 2015.

On the other hand, that the existence of TAHURA Lapak Jaru is related to the Medium-Term Development Plan (RPJM) established by the Gunung Mas Regional Planning and Development Agency (Bappeda) in maintaining the balance of the environment and the social economy as follows: 1) conducting conservation in water catchment areas 
and protected area; 2) build quality regional infrastructure and facilities to fulfill basic rights in the context of realizing the objectives of a balanced spatial planning based on conservation; 3 ) controlling activities that have the potential to damage the environment (Interview A, 18 May 2015). The benefits of Tahura Lapak Jaru are as a catchment water area and also as a water supply for Sakatajuri Dam which covers 50 hectares. Sakatajuri Dam was built by the Ministry of Public Works in 1996 and serves strategically as a source of water for irrigation of 564 hectares of community rice fields and also inland fisheries for the people of Kuala Kurun. The existence of agricultural land and rice production managed by Dayak communities and migrants from Java and Sunda have a positive correlation to rice distribution and community 'food security' in Gunung Mas Regency (Interview Y, 13 May 2015). As known that rice production by Gunung Mas district was sold to other districts in Central Kalimantan due rice surplus production. Another rational reason, put forward by supporters of the pro-establishment of Tahura, is that the existence of Tahura (Taman Hutan Raya) is an attempt by the local government to save protected forests from encroachment by private companies for plantations. Thus, the stipulation of Tahura also does not diminish the rights of local communities to hunt and collect forest products. Actually, the determination of Tahura 10 years ago (20042005) also involved local communities and most of them agreed (Interview B, 12 May 2015). The Tahura program and a large field area for camping activities for scouts and high school (SMA) and junior high school (SMP) students from Gunung Mas Regency and other districts are used as camping and environmental tours is a famous cite on weekends. Besides, those who opposed Lapak Jaru as the location of Tahura were represented by Eprayen Punding ${ }^{4}$ and his fellow Dayak Kuala Kurun elders. The reason for the refusal to be made Tahura was because the area was a customary forest and had been managed decades ago for community gardening and was also a place for ritual ceremonies for Dayak tribal religious practices. According to Punding's opinion, the area of the core customary land in the Tahura location is estimated to be around 3,000 hectares, plus 2,000 hectares for gardening and farming for community members. Punding as a member of the Kuala Kurun Dayak leadership said: "We will continue to refuse at any time. We will not step down even an inch to defend our ancestral lands, and the Tahura program must be canceled immediately, he added' [17]. Struggle in land conflicts to reclaim land in Tahura to the provincial government office to meet with the Governor of Central Kalimantan Teras Narang (2014) in the city of Palangka Raya, but failed, because at that time, the Governor had an out-of-region service, and was met in a discussion by Siun Jarias, Regional Secretary of the province.

In addition to social forestry practices and the application of customary forest to the allocation of Tahura in Lapak Jaru,

4 Eprayen Punding is one of head representative of Dayak Kuala Kurun who struggles reclaim of 'customary forest' land in Tahura cites. He advocated Tahura cite for using again customary forests for vegetable plantation, hunting animals and practice for religious ceremonies among Dayak traditions. there is also the implementation of 'village forest' which was granted by the government to manage forest resources for 35 years to local communities. According to the regulation of the Minister of Forestry number P 89 / Menhut-II / 2014, article 5 concerning village forests, the criteria for forest areas that can be stipulated by the Minister are in protected forest areas and production forests that have not been burdened with rights or permits in the utilization of forest products, and become a source livelihoods of local communities. In the context of protected forest areas, the community is permitted to use area activities, collect nontimber forest products and use environmental services. Whereas for limited production forest areas, namely by utilizing timber forest products while still prioritizing forest sustainability as a source of seeds, water sources and germplasm sources as well as maintaining the security of village forest work areas from encroachment, shifting cultivation, illegal logging and forest fires (District Forestry Service, Gunung Mas, Village Forest Regulation, 2014). There are several village forests that have obtained permits. Firstly, an area of $440 \mathrm{Ha}$ in a permanent production forest area by the government decree of the Minister of Environment and Forestry (KLHK) Number 57 / Menhut-II / 2015 in Rabambang village, Rungan Barat district. According to the village consultation decision, the village institution that manages together with the community, that is, more than half of the land is planted with rubber and local woods such as Meranti, Kapur, ironwood, Tengkawang and agro forestry including palm trees, resin and fruits such as durian, rambutan, jengkol, petai, etc. which have a selling value in the market (Figure 4).

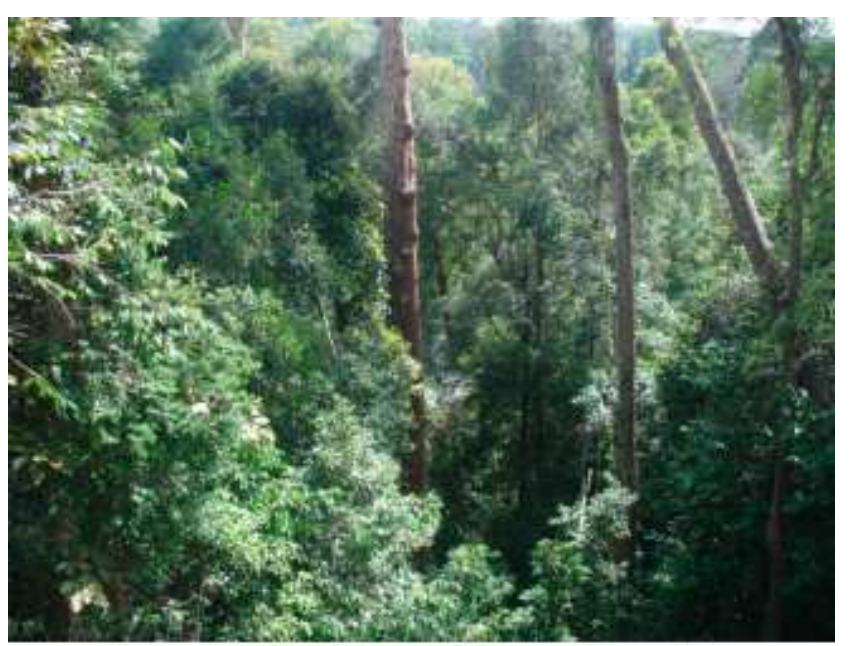

Sumber: Arsio Dinas Kehutanan Kabupaten Gunurs Mas

Source: Forestry Agency Office, Gunung Mas District, 2015.

Figure 4. Rabambang village where Social forestry are planted.

Secondly, Ministry of Environment and Forestry Ministerial Decree number 86 / Menhut-II / 2015 concerning the establishment of a forest working area for Hiran Village covering an area of 865 hectares in a protected forest area in Miri Minasa District. Thirdly, Ministry of Environment and Forestry Ministerial Decree number 58 / Menhut-II / 2015 
concerning the determination of the Harowu village forest area of 1,750 hectares, consisting of 1,720 hectares in protected forest areas and the remaining 30 hectares in limited production forest areas in Miri Minasa District. In this village forest management, the management is organized by a Village Institution, with a chairman, a secretary and sections. According to the opinion of village officials, NGO managers and local community informants, the presence of 'village forest' management in various villages and subdistricts in Gunung Mas district can open productive employment opportunities in the village, cash flow of money in the village and increase the economy and community welfare local present and future (Interviews C, D, and E, 15 May 2015).

\section{Conclusion}

Damage to forest 'ecosystems' caused by expansion of oil palm plantations, logging forest concessions/HPH), industrial timber plantations/HTI, gold mining activities along rivers and community land on land, creation of protected forest 'Lapak Jaru' and 'Sakatajuri' dam for irrigation agricultural sector - resulting in land conflicts with local Dayak communities and 'ecological damage' including forest fires, soil erosion, flood, water and air pollution. This is related, because of air pollution (fog), metallic water waste and the influence of 'pesticide' fertilizers during the rainy season, a solution of mercury and fertilizer flows into the tributaries of the Kahayan River. The economic, social and ecological impacts of the community are adversely affected, because the river biota, both dead fish and shellfish, and the water consumed by the community is polluted, especially during the dry season. Thus, the destruction of the forest ecosystem and its economic and social implications affects the 'social resilience' of the community.

What are the roles of other stakeholders, including local and central government as well as administrators of NGOs and academics? Government programs to alleviate the impact of economic, social and ecological losses in the community, the government, especially the Ministry of Environment and Forestry issued a 'social' forestry 'policy for participation on forest resources management and facilitating by NGOs and academic guidance, by providing economic incentives (credit) from government banks, provision of agro-forestry seeds and training on human resources and market access.

\section{Acknowledgements}

We would like to thank Indonesian Institute of Sciences (LIPI) for the funding support of this field research in Central Kalimantan, Jambi, and North Sumatra provinces of 'forest resources management and social resilience' program for the fiscal year project 2014-2015. My sincerely thanks also to reviewers, and several significant informants for interview and participation observation to their fields from government officers (Forestry Agency in district and province as well),
Development and Planning Agency Service in district and province level, NGOs officers, academics, head of Dayak customary rights (Mantir and Damang), local communities in some villages and sub-districts in Gunung Mas district, Central Kalimantan. This findings from this research suggest as follows:

1) The implementation of law enforcement by the government officers toward private companies and local community who actively involved on 'deforestation and ecological damage' for instance water and weather pollution, flood, soil erosion, forest fires should be punished in the state court.

2) To empower 'social resilience' among local community who live in surrounding forest and in forest, 'affirmative program' on 'social forestry' (Perhutanan Sosial) for planting agroforestry which has issued by central government throughout Ministry Environment and Forestry should be supported by other stakeholders (private company, local government, NGOs, academic, local people), and so forth.

3) Lapak Jaru cite in upstream should be kept as protected forest as means for catchment area, conservation area for biodiversity and water supply for Sakatajuri Dam functioning water irrigation for agricultural fields.

\section{References}

[1] Hidayat, Herman. 2008. Politik Lingkungan: Pengelolaan Hutan Masa Orde Baru dan Reformasi (Jakarta: Pustaka Obor Press).

[2] Hidayat, Herman. 2016. Forest Resources Management in Indonesia: A Political Ecology Approach (Singapore: Springer Press).

[3] FWI/GFW. 2001. Keadaan Hutan Indonesia (Bogor, Indonesia: Forest Watch Indonesia and Washington D. C: Global Forest Watch Forum).

[4] Pearce, D. W. 2001." The Economic Value of Forest Ecosystems" in Ecosystem Health 7 (2), pp. 284-296.

[5] Webersick, Christian. 2010. Climate Change and Security (California: Prager Press).

[6] Berkes et al., 2012. "Introduction" in E. Boyd and C. Folke (eds.) Adapting Institution: Governance, Complexity and Social Ecological Resilience (New York: Cambridge University Press), pp. 1-9.

[7] "Foreign Exchange Earnings of Oil Palm and Crude Palm Oil (CPO): Trading in 2019-2020" (Access in Google, 13 January 2021)

[8] Slette, J. P and Wiyono, I. E. 2011. 'Oilseeds and Products Update Indonesia 2011, 11 pp., USDA Foreign Agricultural Service.' Retrieved 21 July, 2013, from http://gain.fas.usda.gov/Recent\%20GAIN520Publications/Oils eeds\%20and $\% 20$ Products\%20Update_Jakarta_Indonesia_128-2011.pdf. 
[9] Obidzinski, K et al., 2012. "Environmental and Social Impacts of Oil Palm Plantations and Their Implications for Biofuel Production in Indonesia", in Ecology and Society 17 (1): 25.

[10] Kompas, 15 September 2011.

[11] Walker, A. 2001. 'Karen Consensus, Ethnic Politics and Resources Use Legitimacy in Northern Thailand' in Asian Ethnicity 2 (2) pp. 145-162.

[12] Clausen, F, M. L. Barreto, and A. Attaran. 2011. "Property Rights Theory and Reform of Artisanal and Small-Scale Mining in Developing Countries" in Journal of Politics and law 4 (1) pp. 15-26.

[13] Inswiasri, Kusnoputranto, H. 2011. "Pajanan Hg pada Petambang Emas Tradisional di Kabupaten Gunung Mas-
Kalimantan Tengah: Mercury Exposure of Traditional Miners in Gunung Mas District, Central Kalimantan", in Ekologi Kesehatan 10 (2) pp. 72-82.

[14] Lindayati, Rita, "Gagasan dan Kelembagaan Dalam Kebijakan Perhutanan Sosial", dalam Resosudarmo, Ida Ayu Pradnja and Colfer, Carol J. Pierce (eds.) 2003. Ke Mana Harus Melangkah?: Masyarakat, Hutan. Dan Perumusan Kebijakan di Indonesia (Jakarta: Yayasan Obor Indonesia), pp. 43-44.

[15] Hidayat, Herman (eds.). 2019. Deforestasi dan Ketahanan Sosial (Deforestation and Social Resilience) (Jakarta: Yayasan Obor Pustaka Indonesia).

[16] Kompas, 13 Januari 2021.

[17] Harian Terbit, 19 Mei 2015. 